\title{
Chapter 36 \\ EXPERIMENTAL DATA ON THE OVERTOPPING OF SEAWALLS BY WAVES
}

\author{
A.Paape \\ Hydraulics Laboratory, Delft, Netherlands.
}

\section{INTRODUCTION}

In the past it has been found that serıous damage and breaching of seawalls is most frequently caused by overtoppinis. Hence for the design of seawalls data must be avallable about the overtopping by waves of the different profiles that might be posslble. Naturally the conditions unded which damage is caused to the seawall also depend on the type of construction and the materials used, for example: the stability of grass covered dikes can be endangered seriously by water flowing over the innes slope.

In many designs the necessary helght of a seawall has been defined such that not more than $2 \%$ of the waves overtop the crest, under chosen deslgn conditions. This crlterlon has been determined on the assumption that the overtopping must remain very small. Some overtopping has to be accepted because no maximum value for wave helght and wave run-up can be glven, unless of course the wave helght is limited by fore-shore conditi ons.

Unfortunately this criterion gives no information about the volume and concentration of water overtopping the crest in each instance. Moreover it is of interest to know how this overtopping varles with other condltions, such as changes in the signiflcant wave helght.

Information about the overtopping by waves was obtazned from model investigations on simple plane slopes with inclinations varyins from $1: 8$ to $1: 2$. The experiments were made in a windflume where wind gene ated waves as well as regular waves were employed.

Using wind generated waves, conditions from nature regarding the distribution of wave helghts could be reproduced. It appeared that the overtopping depends on the irregularity of the waves and that the same effects cannot be reproduced using regular paddle generated waves.

In this paper a description of the model and the results of these tests are glven. Investigations are in prosress on composite slopes, including the reproduction of conditions for a seawall which suffered much overtopping but remained practically undamaged during the flood of 1953 .

\section{WAVE CHARACTERISTICS}

The helghts of a serles of wind waves ire often characterlzed by the value of the signiflcant wave helght $\mathrm{H}_{1} / 3$, that is the average of th highest third part of such a serles. More information ls obtalned by mea of a wave height distribution curve. For this purpose the value $H$ has been defined as the helght which 1 s exceeded by $n \%$ of the waves of a serles (e.g. $\mathbb{H}_{10}$ is the helght exceeded by $10 \%$ of the waves). It has been found approximately that $\mathrm{H}_{1 / 3}=\mathrm{H}_{13^{\circ}}$. 


\section{EXPERIMENTAL DATA ON THE OVERTOPPING OF SEAWALLS BY WAVES}

Wave helght distribution curves are given in figure 1 for wind velocities of $4,6,8$ and $10 \mathrm{~m} / \mathrm{sec}$ in the wind flume, wh th a fetch of $50 \mathrm{~m}$. A comparison between the different wave helght distributions is made in figure 2, where, instead of the absolute value of the wave helght, the ratıo $\mathrm{Hn} / \mathrm{H} 50$ has been plotted. From this it appears that for lower wind velocities the waves become more irregular.

Similar dıstribution curves were obtaıned from wave-records made along the Dutch coast, examples are given in figure 3. It can be seen from these figures that the wave helght distribution of nature can be reproduced in the windflume.

In many experiments the wand velocity has been chosen according to the wave helght distribution to be reproduced. Then no direct relationship between the wind velocities in prototype and model exists and it has often been found that the wind velocity in the model is greater than that given by the Froude model law. This seems to be due to the fetch not being to scale.

In studying wave run-up and overtopping, attention should be pald to the wind velocity just in front of and above the model.

The wave period is determined as the mean value of a series of waves. The mean wave length can be found from perlod and water depth. For wind generated waves in the windflume the mean period varies from $0.65 \mathrm{sec}$ with a wind velocuty of $4 \mathrm{~m} / \mathrm{sec}$. to $0.85 \mathrm{sec}$ with a wind reloc.l ty of $10 \mathrm{~m} / \mathrm{sec}$.

When the wave helght and period, using wind only, is too small, a regular paddle generated swell can be applied in combination with a rather high wind velocity to obtain the required perıod and wave height distribution.

In these experiments only whd was used.

\section{CON ITRUCTION OP THS MODEL}

The model was arranged as shown in figure 4; the lower part of the slope was made of plywood whlle the upper part whlch was integral with the collecting tank was made of steel sheet. The helght and inclination could be readly adjusted.

The model had a wldth of $0.5 \mathrm{~m}$ and was placed in a rlass wall flume, which formed part of a windflume, $4 \mathrm{~m}$ wide and $50 \mathrm{~m}$ long.

Before the model was placed, series of tests showed that the subdivision of the main flume had no effect on measured wave characteristics.

During the tests the wave he shts were measured by means of a parallel wire resistance gauge and recorded by a pen-writer. The gauge was located in the portion of the flume not occupled by the model. The overtopping was measured as the volume of water passing the crest during each test.

\section{EXPRRIMLNTS}

Each series of tests consisted of measurements vith a fixeci inclination, varyın crest he $\tau_{S}^{r h}$ t and a constant vind velocity. For every 


\section{COASTAL ENGINEERING}

helght of the crest the overtopping was measured as the volume of water passing the crest during $600 \mathrm{sec}$, from which an average value per secon could be determined. Also the number of overtopping waves, as a percent of the total number was determined. During each run waves were registra for 120 sec. In this way an average distribution from about 2000 wave helghts was obtained for each slope and wind velocity.

Tests were carried out for the following conditions:

\begin{tabular}{|c|c|c|c|c|c|c|c|}
\hline \multirow{2}{*}{ Slope } & \multicolumn{6}{|c|}{ Wind velocity in $\mathrm{m} / \mathrm{sec}$ (model) } & \multirow{2}{*}{$\begin{array}{l}\text { Regulas } \\
\text { waves }\end{array}$} \\
\hline & 4 & 6 & & 8 & & 10 & \\
\hline 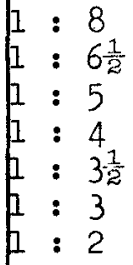 & $\mathrm{x}$ & $\begin{array}{l}x \\
x \\
x\end{array}$ & $\mathrm{x}$ & $\begin{array}{l}x \\
x \\
x \\
x \\
x \\
x \\
x\end{array}$ & $\mathbf{x}$ & $\begin{array}{l}x \\
x \\
x \\
x \\
x \\
x \\
x\end{array}$ & $\begin{array}{l}x \\
x\end{array}$ \\
\hline $\begin{array}{l}\text { depth } \\
(\mathrm{m})\end{array}$ & 0.30 & 0.30 & 0.25 & 0.30 & 0.35 & 0.30 & 0.30 \\
\hline
\end{tabular}

Moreover an investigation was made in which, for series of wind generated waves, those waves causing overtopping were indioated on the wave recording.

\section{RESULTS}

OVTRTOPPING BY WIND GENERATED WAVES.

An attempt has been made to express the results of these tests ir terms of dimensionless parameters as follows. The height of the crest c the seawall above still water level, $h$, was expressed as the ratio

$$
\mathrm{h} / \mathrm{H}_{50^{\circ}}
$$

It was found that the overtopping could be related to the dimensions of the waves using the ratio.

$$
\frac{2 \pi 2 \mathrm{~T}}{\mathrm{H}_{50} \mathrm{~L}} \text {. }
$$

\section{In these parameters means:}

$\mathrm{h}$ = height of the crest of the seawall above still waterlevel :

$Q=$ overtopping in $\mathrm{m}^{3} / \mathrm{sec}$ per $\mathrm{m}$ length of the seawall

$\mathrm{T}$ = wave period in sec. 
EXPERIMENTAL DATA ON THE OVERTOPPING OF SEAWALLS BY WAVES

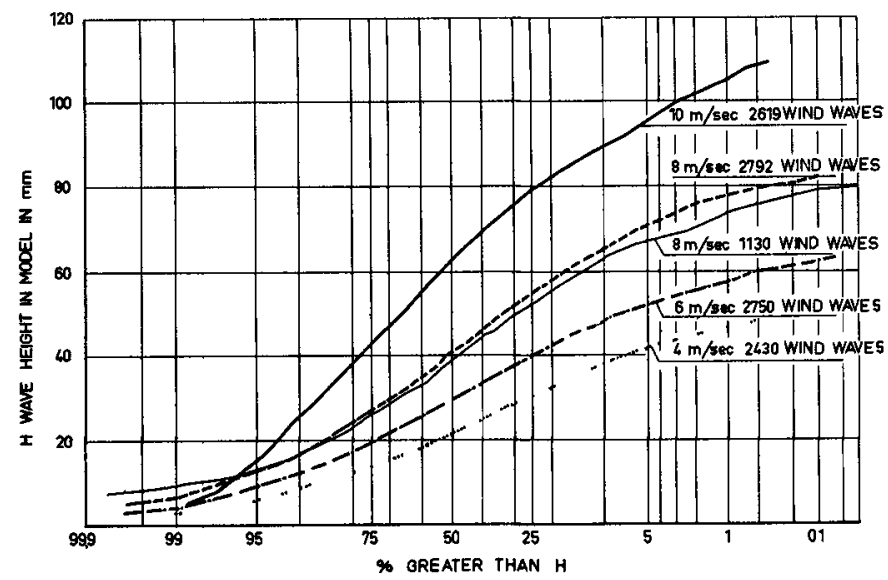

Fig. 1. Wave height distribution in wind flume.

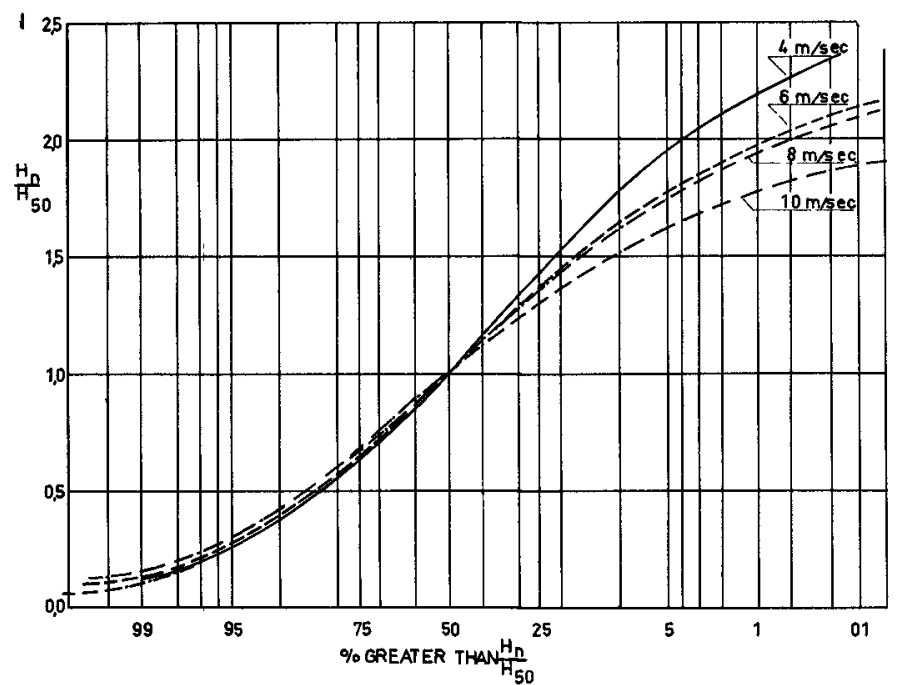

Fig. 2. Distribution of relative wave heights in

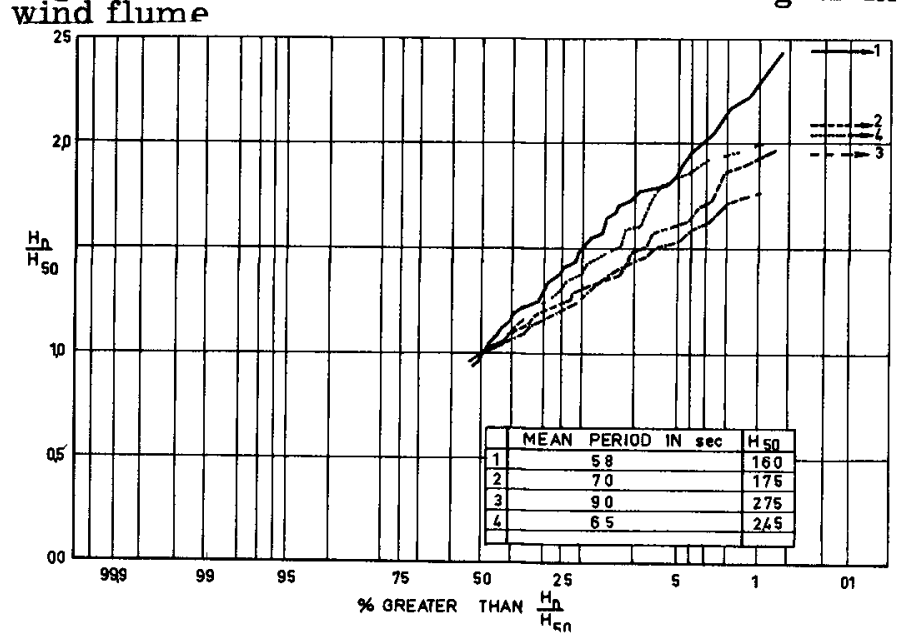

Fig. 3. Distribution of relative wave heights at Katwijk . 
COASTAL ENGINEERING

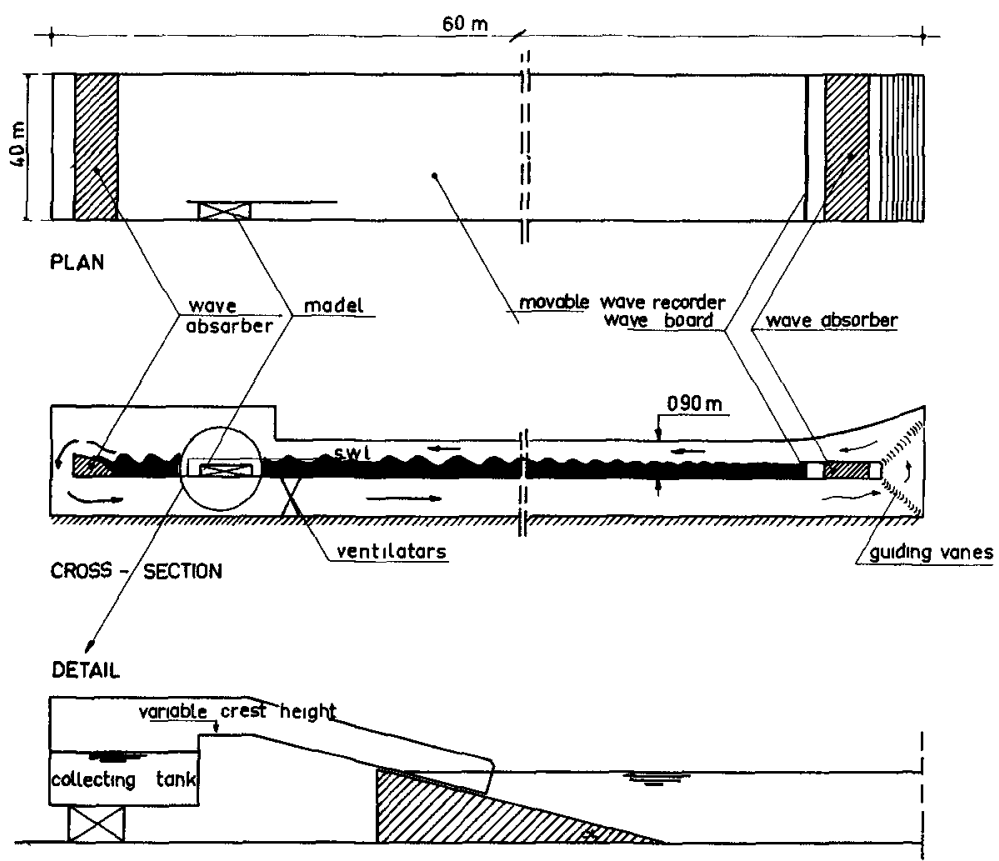

Fig. 4. Arrangement of the model.

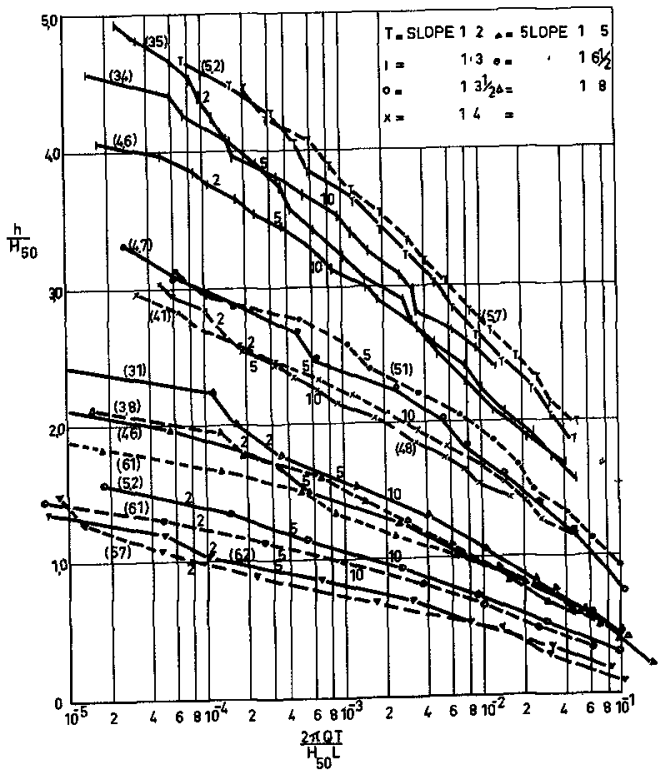

Fig. 5. Overtopping for different slopes. Numbers in brackets indicate wave steepness in \%. Plain numbers indicate percentage of waves overtopping.

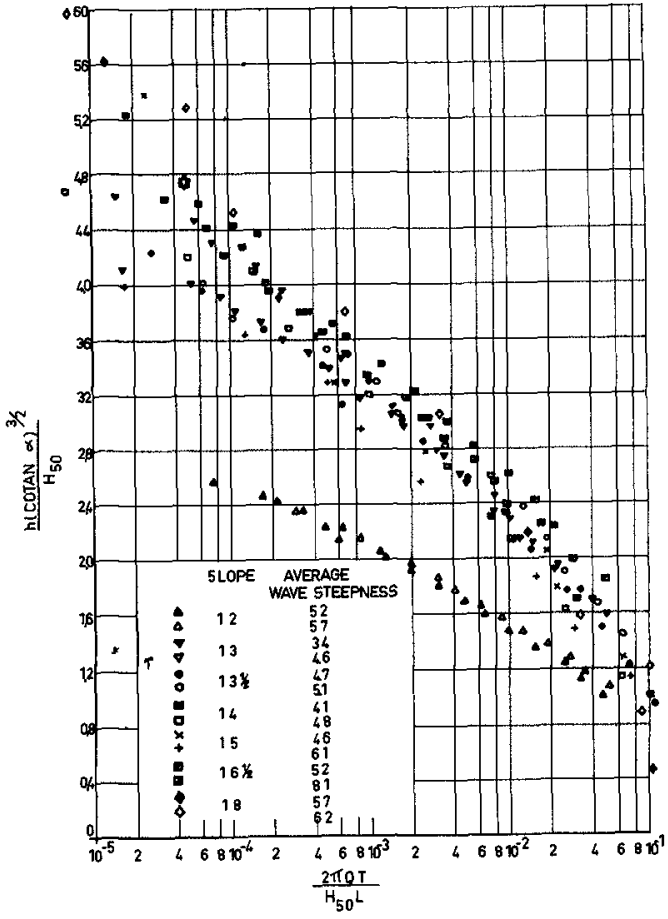

Fig. 6. Over topping as function of $\mathrm{h}(\operatorname{cotan} \alpha)^{3 / 2}$

$\mathrm{H}_{50}$ 


\section{EXPERIMENTAL DATA ON THE OVERTOPPING OF SEAWALLS BY WAVES}

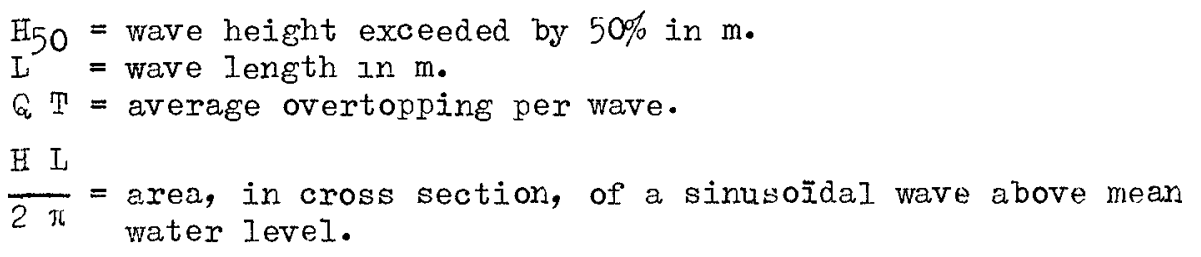

These results are given in flgure 5. For each slope curves for different average wave steepness vere obtained, as various wind veloclties we:'e applied. Also the percentage of the waves causing overtopping is indlcated. From the tests carried out on a slope of 1 : 5, the same results were obtained for a water depth of $0.25,0.30$ and $0.35 \mathrm{~m}$. The wave length in deep water, $\mathrm{I}_{1}$, according to the periods used in these tests was approximately $1.2 \mathrm{~m}$, so no influence of the water depth, $d$, was found for $d / I_{0} \geqslant 0.21$.

In comparing the results for the different slopes, in order to establish the influence of the angle of inclination $\alpha$, it appeared that the volume of water overtoppins the crest is not proportional to tan $a$. (From former jnvestigations it appeared that the wave mun-up exceeded by $2 \%$ of the waves, $z_{2}$, could be expressed as $\left.\mathrm{Z}_{2}=8 \mathrm{H}_{1 / 3} \tan \alpha\right)$.

The best results have been obtained using the assumption that the overtopping is proportional to $(\tan a)^{3 / 2}$, which is shown in

$$
\text { figure } 6 \text { where, instead of } h / H_{50}, \frac{h(\operatorname{cotan} \alpha)^{3 / 2}}{H_{50}} \text { has been plotted. }
$$

It is seen that wath slopes varylng from $I: 3$ to $1: 8$ the results can be represented by a single line. But for a slope of $1: 2$ the results are completely different, possibly due to greatly increased reflection of wave energy for the steeper slopes.

\section{Restriction.}

It should be noted that there are probably limitations to the applicability of these results and that the experiments reported here were Ilmited to the ranges:

and

$$
0.03<\frac{I_{50}}{I_{0}}<0.06
$$

$$
d / I_{0} \geqslant 0.21 \quad \text { in which: }
$$

d. = water depth

$\mathrm{L}_{\mathrm{O}}=$ wave length in deep water

Although the full range to which the results can be applied is not known, It is evldent that for small water depths the ratio. T/L approaches

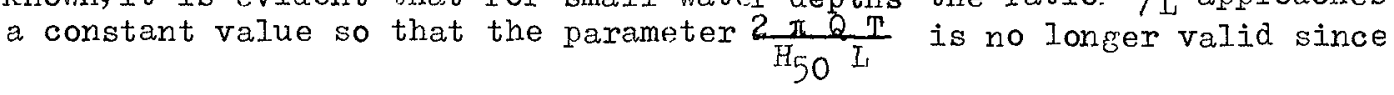




\section{COASTAL ENGINEERING}

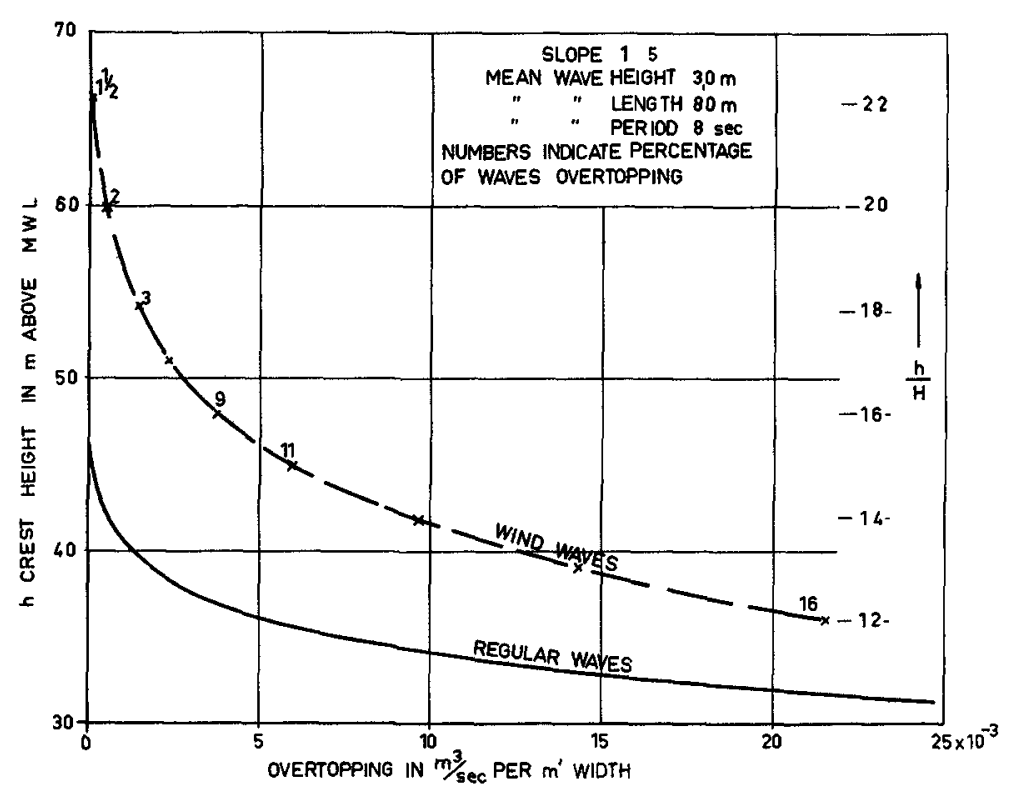

Fig. 7. Overtopping of regular and wind waves .
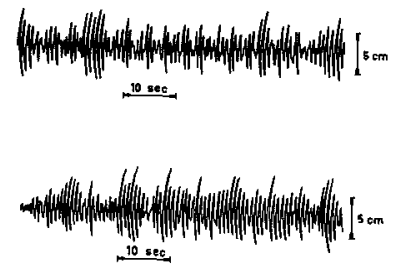

Fig. 8. Example of record. Overtopping waves are dotted.

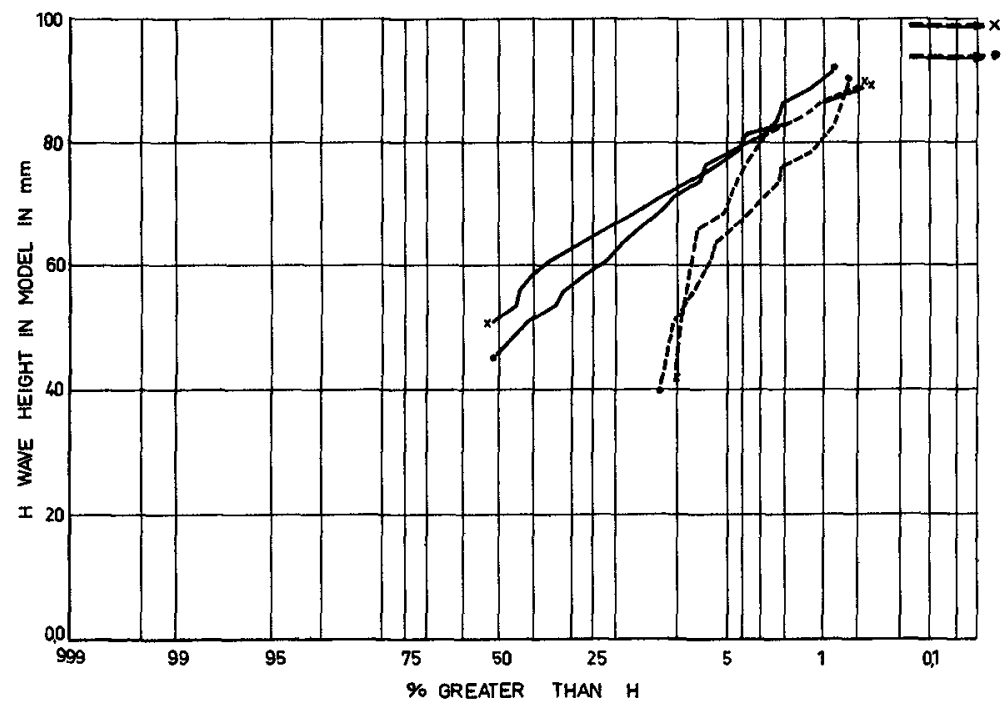

Fig. 9. Distribution of all wave heights (full line). Dis tribution of overtopping wave heights (dotted). 


\section{EXPERIMENTAL DATA ON THE OVERTOPPING OF SEAWALLS BY WAVES}

It does not include the influence of wave length and period.

OVERTOPDING BY RTGULAR AND IRREGULAR WAVES.

The nvertopping has been measured for regular and irregular waves wl th the same mean helght. The results are glven on figure 7 .

As could be expected, the irregular waves produced more overtopping. It can also be seen from this figure that there is no simple relationship between the helght of a regular wave whlch will give the same overtopping as a glven irregular weve, because the height of the seawall crest must also be taken into account.

If there was a direct relationship between the overtopping and the helght of individual waves it would still be possible to estrmate the total overtopping from a serles of tests with regular waves of various heights by multıplying each overtopping quantity in proportion to the percentage of waves of that helght occurring in the spectrum.

Flgure 8 gives an example of a wave record in which the overtopping waves are indlcated and from whlch it can be seen that the overtoppins, does not depend only on the height and length of the individucl waves. This is also lllustrated in figure 9 where as a result of these tests ware helght distribution curves are given for all the waves exceeding HLo and for the overtopping waves. The percentage relates to the total number of waves in the series. When $n \%$ of the waves causes overtopping it is certainly not the highest no which is involved. So a direct relationship between the overtopping and the height of Individual waves does not exist.

Obviously these effects of Irregular waves cannot be reproduced by regular waves.

\section{CONCLUSTONS}

a. The overtopping of seawalls depends largely on the Irregularity of waves. The effects cannot be reproduced in a model using regular waves.

b. Statistical distributions of wave helghts in nature, can be reproduced in a windflume of suitable dimensions.

c. In the design of seawalls a better idea about the probability of fallure is obtalned taking as a criterion the volume of overtopping water as well as the percentage of overtopplng waves.

d. When the helght of the crest is based on the criterion of $2 \%$ of waves overtopping, the quantity of overtopping water is very small.

e. For $\tan \alpha<1 / 3$, the volume of overtopping water was found to be proportional to $(\tan \alpha)^{3 / 2}$. 